\title{
35. TERTIARY SILICOFLAGELLATES AND OTHER SILICEOUS MICROFOSSILS FROM THE WESTERN SOUTH ATLANTIC, DEEP SEA DRILLING PROJECT, LEG 39
}

\author{
Katharina Perch-Nielsen, Department of Geology, Swiss Federal Institute of Technology, Zürich, Switzerland
}

\section{INTRODUCTION}

Silicoflagellates and other siliceous microfossils such as archaeomonads, ebridians, and endoskeletal dinoflagellates were found at three sites of Leg 39. The Eocene silicoflagellates of the siliceous sequence at Site 356 are discussed by Bukry (this volume), while the other siliceous microfossils of Sites 354,356 , and 358, and the silicoflagellates of Sites 354 and 358 are discussed in this report. Site localities are shown in Figure 1, and the distribution of siliceous microfossils is given in Tables 1 through 3 . Some ebridians are illustrated in Plate 1.

\section{METHODS OF STUDY}

The samples studied from Sites 354 and 356 were smear slides prepared for coccolith investigations. One sample $(356-7-3,70 \mathrm{~cm})$ was studied using the scanning electron microscope. The samples studied from Site 358 were washed through a $28 \mu \mathrm{m}$ sieve to permit an easier survey of the silicoflagellates. Caedax was used as a mounting medium.

\section{ARCHAEOMONADS}

The Archaeomonadaceae are a family of fossil marine chrysomonadins with cysts composed of $\mathrm{SiO}_{2}$. They probably led a planktonic life in the photic zone. The form and size of the opening in the cyst, the presence or absence of a neck, its form, as well as the size, shape, and ornamentation of the cyst, are used to distinguish genera and species. Archaeomonads occur in upper Cretaceous through Miocene sediments, and probably also in the Pliocene/Pleistocene (PerchNielsen, in press).

Archaeomonads were found in the siliceous sequences at Sites 354, 356, and 358 (see Tables 1-3). With the exception of Litharchaeocystis sp., a bottleshaped form covered with short spines, the species here recorded have been described and illustrated by PerchNielsen (1975, in press). Archaeomonads are unexpectedly absent from most siliceous-fossil-bearing samples of Site 354, and only Archaeomonas inconspicua was found in Sample 12-4, $68 \mathrm{~cm}$ (lower to middle Oligocene). At Site 356 the assemblage of archaeomonads includes seven species of Archaeomonas and two forms of the questionable archaeomonad Litharchaeocystis. This genus was originally described from the Eocene diatomite of Kuznetsk, USSR, and several species were found in Eocene samples from the Norwegian Sea (PerchNielsen, 1976). It is missing from the Eocene

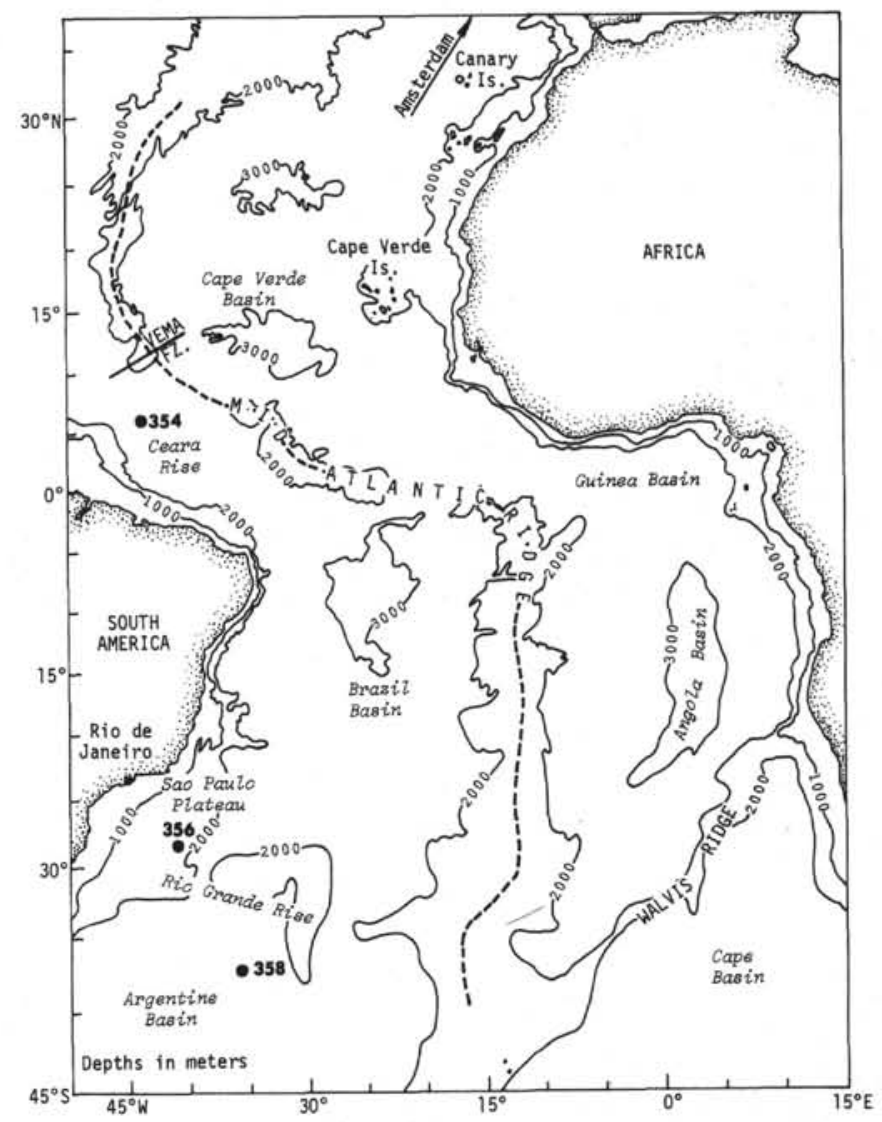

Figure 1. Map showing Leg 39 sites with common siliceous microfossils.

investigated of the subantarctic Southwest Pacific (Perch-Nielsen, 1975). Archaeomonads occur only rarely and sporadically in the upper Oligocene and Miocene of Site 358 in the Argentine Basin.

\section{EBRIDIANS}

Ebridians are marine planktonic organisms that secrete a siliceous skeleton. They are commonly found in cold to temperate waters and their fossil record goes back to the Paleocene. They have higher diversities in the Eocene and Miocene than in other series.

Ebridians were found in the siliceous sequences of Sites 354,356 , and 358. A single specimen of a probably new species (Plate 1, Figures 1, 2) was found in Sample $357-28-6,66 \mathrm{~cm}$ (lower Eocene). In the middle Eocene of Site 356, the ebridian assemblage includes Ammodochium rectangulare, Ebriopsis crenulata, Hermesinop- 
TABLE 1

Middle Oligocene Silicoflagellates and Other Siliceous Microfossils at Site $354^{\mathrm{a}}$

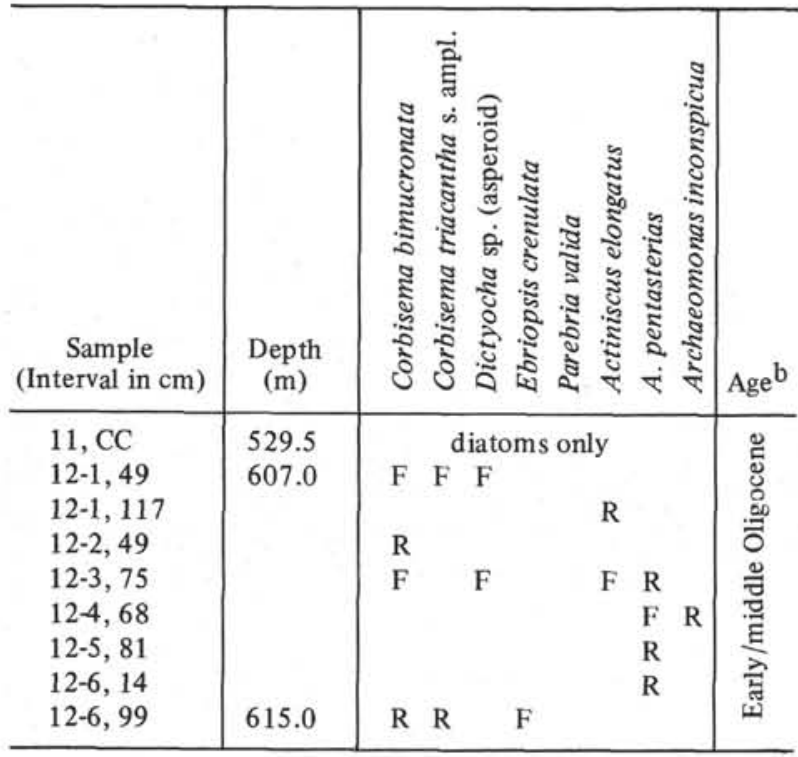

${ }^{\mathrm{a}} \mathrm{F}$ - few; R - rare.

${ }^{\mathrm{b}}$ Age assignment based on calcareous nannofossils (NP21-NP23; Perch-Nielsen, this volume). sis caulleryi, and Pseudammodochium dictyoides. The Oligocene at Site 354 includes only E. crenulata and Parebria valida. Pseudammodochium sphaericum was found in the upper Oligocene, Micromarsupium? sp. in the lower Miocene, and Haplohermesinum simplex in the upper Miocene to Pleistocene of Site 358. These assemblages are less diverse than those found in coeval sediments of the Norwegian Sea and the subantarctic Southwest Pacific (Perch-Nielsen, 1975, in press). While some species, like $A$. rectangulare, E. crenulata, and $H$. simplex, were also found in the Norwegian Sea, only the former two also occur in the subantarctic Southwest Pacific and seem to be widely distributed. Hermesinum geminum, found in the Norwegian Sea and the subantarctic Southwest Pacific, does not occur in the samples studied here.

\section{SILICEOUS ENDOSKELETAL DINOFLAGELLATES AND OTHER SILICEOUS MICROFOSSILS}

Siliceous endoskeletal dinoflagellates are scarce and of limited diversity in most samples studied. The most common form is Actiniscus pentasterias. It was found in the middle Oligocene of Site 354 and in the upper Oligocene through upper Pliocene of Site 358. In addition, A. elongatus occurs in the middle Oligocene of Site 354 and $A$. radicula in the uppermost Oligocene of

TABLE 2

Middle Eocene Siliceous Microfossils at Site $356^{\mathrm{a}}$

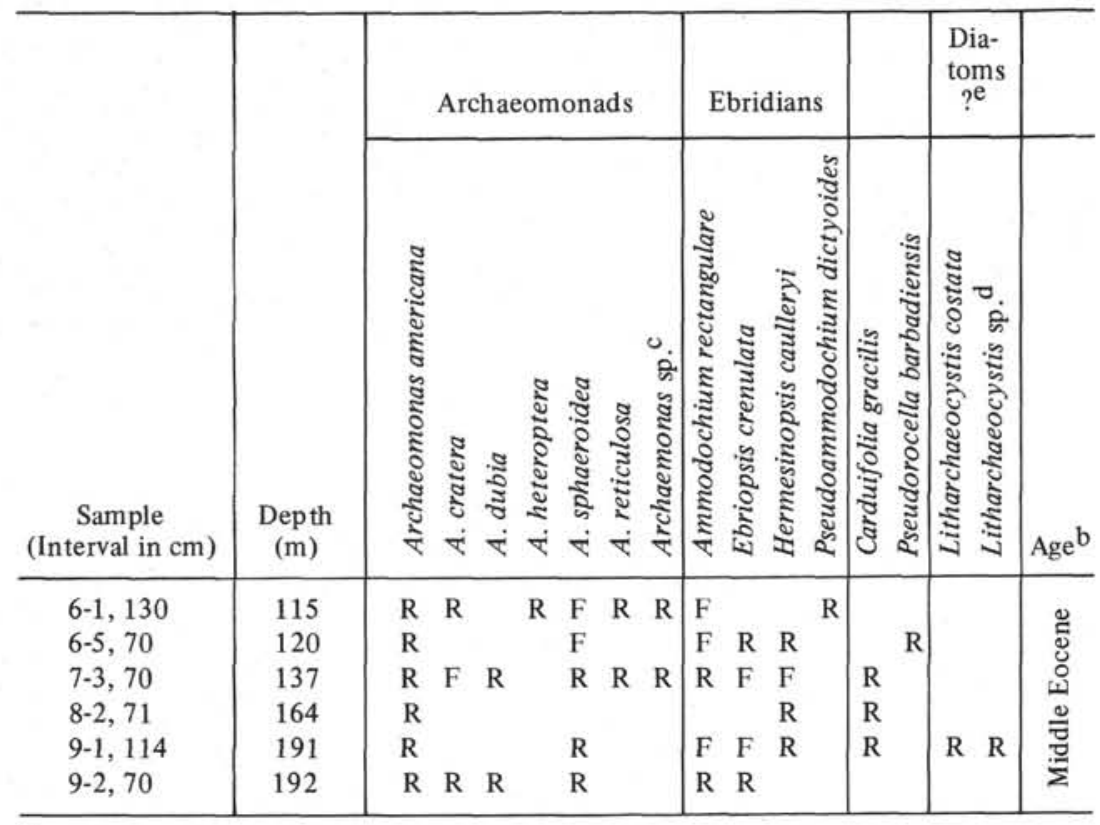

${ }^{\mathrm{a}} \mathrm{F}$ - few ; R - rare.

${ }^{\mathrm{b}}$ Age assignment based on calcareous nannofossils (NP15, NP16).

${ }^{\mathrm{c}}$ Archaeomonas sp. is a small form $(\sim 6 \mu \mathrm{m})$ with a smooth surface, short simple neck, and an irregular to pear-shaped outline.

$\mathrm{d}_{\text {Litharchaeocystis }} \mathrm{sp}$. is a bottle-shaped form with short $(2-3 \mu \mathrm{m})$ spines covering the body except for the simple neck.

${ }^{\mathrm{e}}$ Litharchaeocystis is usually treated as an archaeomonad, but since the neck is always broken, it might well be a diatom. 
TABLE 3

Upper Oligocene, Miocene, and Pleistocene Silicoflagellates and Other Siliceous Microfossils at Site $358^{\mathrm{a}}$

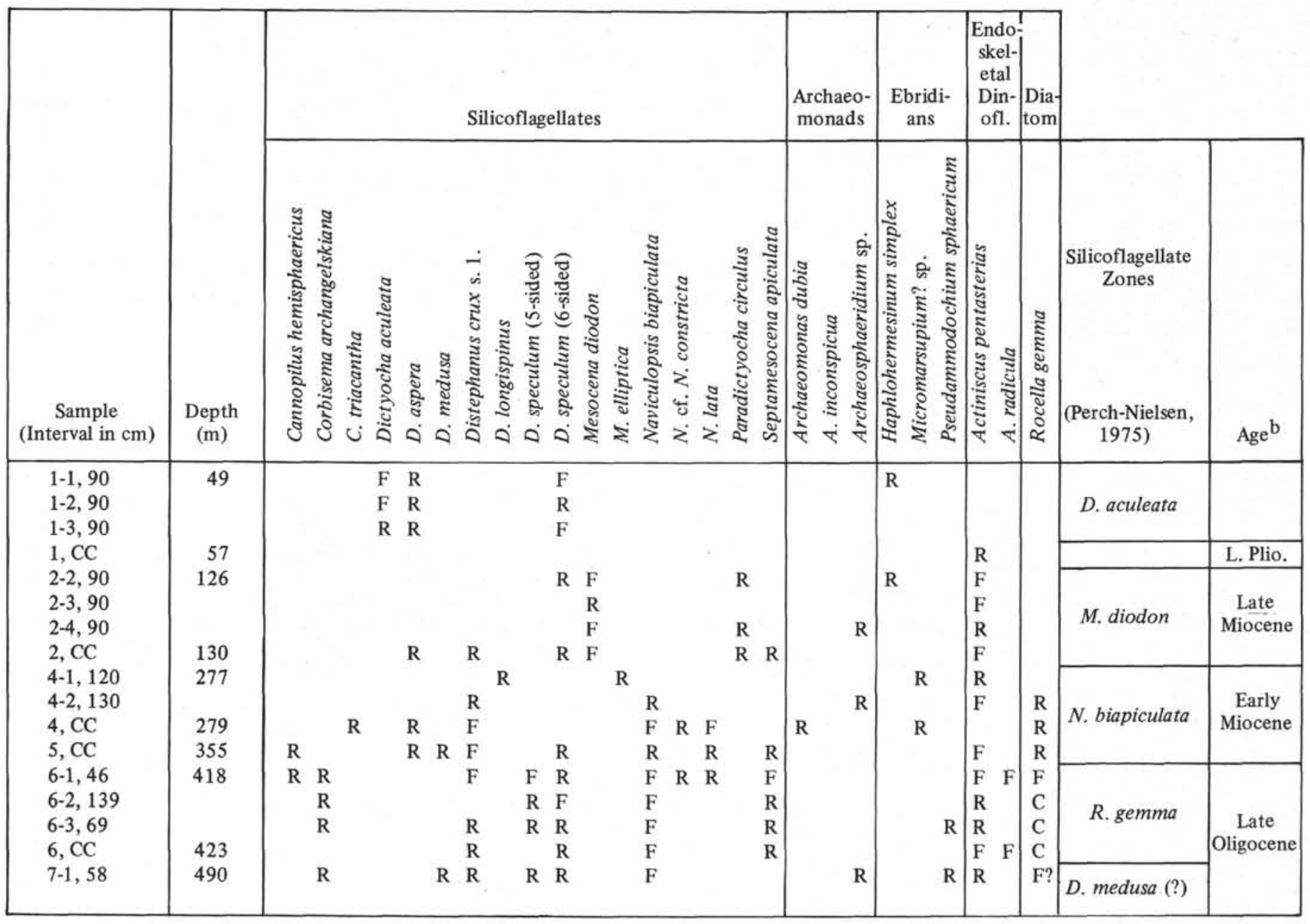

${ }^{\mathrm{a}} \mathrm{C}$ - common; F - few; $\mathrm{R}$ - rare.

${ }^{\mathrm{b}}$ Age assignments based on silicoflagellates (Cores 1, 2, and 6) diatoms (1, CC) and radiolarians (Cores 1, 4, 5, and 7).

Site 358, a form described by Dumitrica (1973) from the Miocene of the New Caledonia Basin.

Forms of Pseudorocella, an incertae sedis genus usually treated with the silicoflagellates, occur in the middle Eocene of Site 356 and in the lower Miocene of Site 358. Rocella gemma (= Stictodiscus gelidus, the diatom usually treated with the silicoflagellates) occur commonly in the upper Oligocene of Site 358 and rarely in the lower Miocene of the same site.

\section{SILICOFLAGELLATES}

The richest and best preserved assemblages of silicoflagellates were found in the middle Eocene sequence of Site 356 on the São Paulo Plateau. These have been studied in detail by Bukry (this volume) who assigned them to the Dictyocha hexacantha and Naviculopsis foliacea zones.

At Site 354, a few silicoflagellates were found in the core catcher of Core 11 and in Core 12 (lower to middle Oligocene). The assemblage includes only Corbisema bimucronata, $C$. triacantha, s. ampl., and asperoid Dictyocha. No zonal assignment can be made.
At Site 358 in the Argentine Basin, silicoflagellates were found only in samples in which diatoms are common and relatively well preserved. The presence of Dictyocha aculeata in sections 1 through 3 of Core 1 suggests a late Pleistocene age. No silicoflagellates were found in the core catcher, which was assigned a late Pliocene age on the basis of radiolarians and diatoms.

The presence of Mesocena diodon and Paradictyocha circulus assigns Core 2 to the upper Miocene $M$. diodon Zone. No siliceous microfossils were found in Core 3. Cores 4 and 5 contain somewhat richer assemblages than above. Present are Naviculopsis lata, N. biapiculata, Distephanus crux s.1., and Dictyocha aspera. Rocella gemma (= Stictodiscus gelidus) is scarce and these cores are assigned to the lower Miocene $N$. biapiculata Zone.

The assemblage in Core 6 is characterized by common $R$. gemma which, together with five-sided Distephanus speculum and rare Corbisema archangelskiana also occur in Sample 7-1, $58 \mathrm{~cm}$, the lowermost sample including silicoflagellates at Site 358 . These assemblages are of late Oligocene age. 


\section{REFERENCES}

Dumitrica, P., 1973. Cenozoic endoskeletal dinoflagellates in Southwestern Pacific sediments cored during Leg 21 of the DSDP. In Burns, R.E., Andrews, J.E., et al., Initial Reports of the Deep Sea Drilling Project, Volume 21: Washington (U.S. Government Printing Office), p. 819 835.

Perch-Nielsen, K., 1975. Late Cretaceous to Pleistocene Archaeomonads, Ebridians, Endoskeletal Dinoflagellates, and other siliceous microfossils from the subantarctic
Southwest Pacific, DSDP Leg 29. In Kennett, J.P., Houtz, R.E., et al., Initial Reports of the Deep Sea Drilling Project, Volume 29: Washington (U.S. Government Printing Office), p. 677-722.

in press. Eocene to Pliocene Archaeomonads, Ebridians and endoskeletal dinoflagellates from the Norwegian Sea, DSDP Leg 38. In Talwani, M., Udintsev, G., et al., Initial Reports of the Deep Sea Drilling Project, Volume 38: Washington (U.S. Government Printing Office). 
PLATE 1

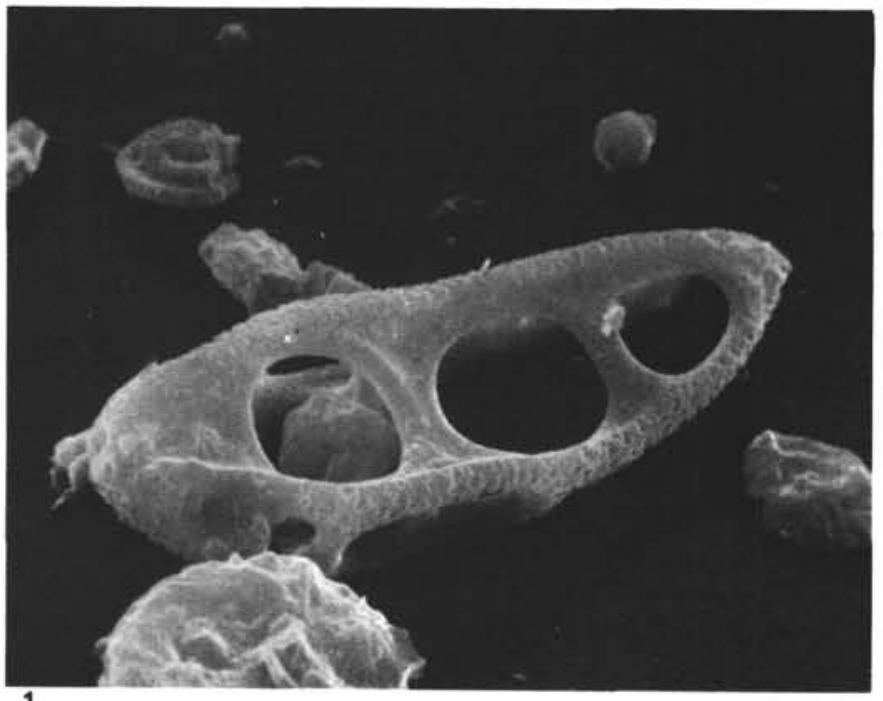

1

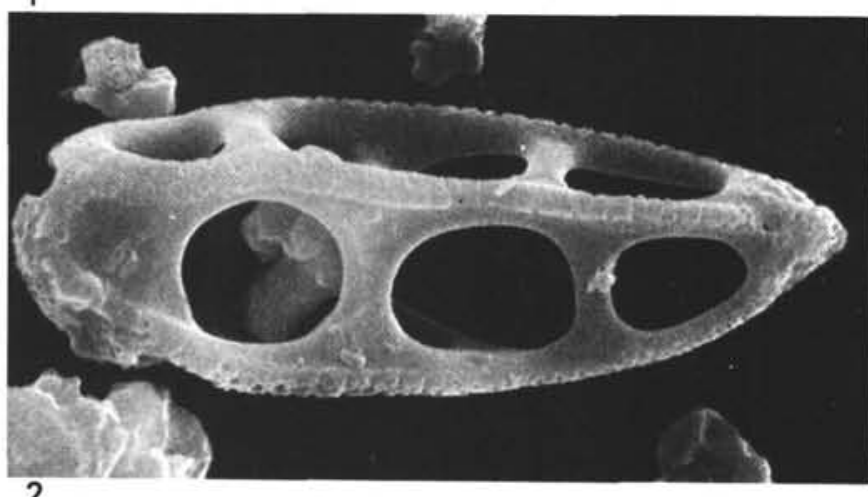

2

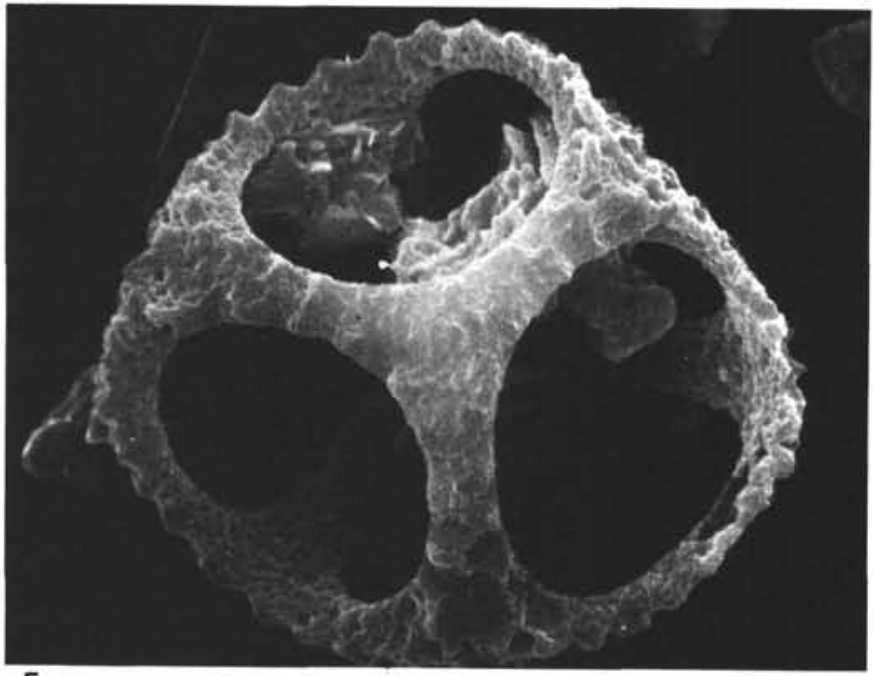

5

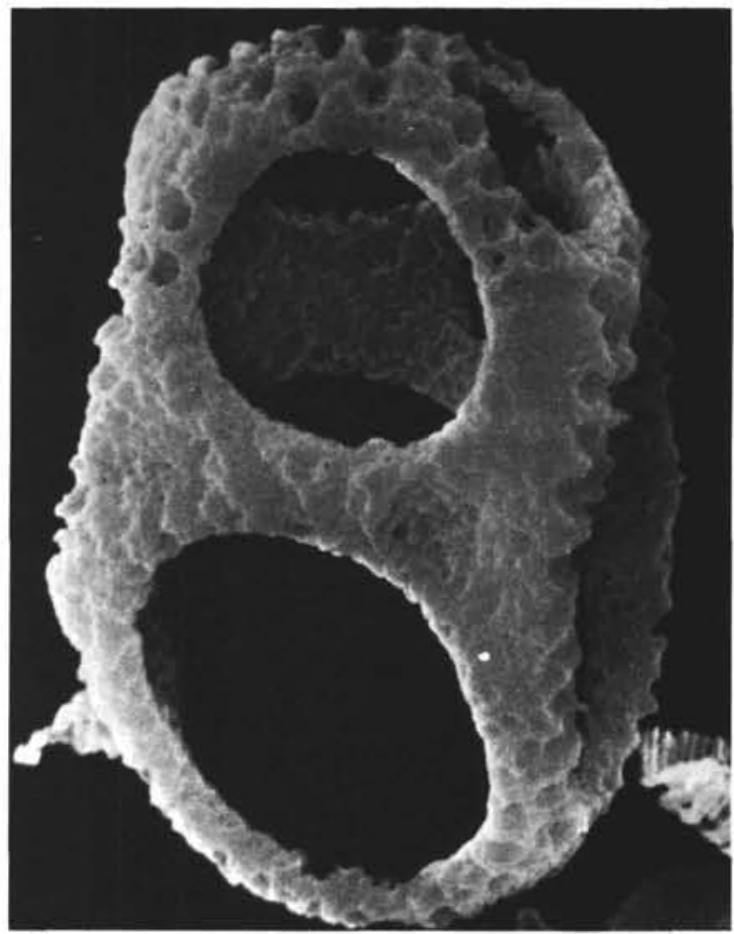

3

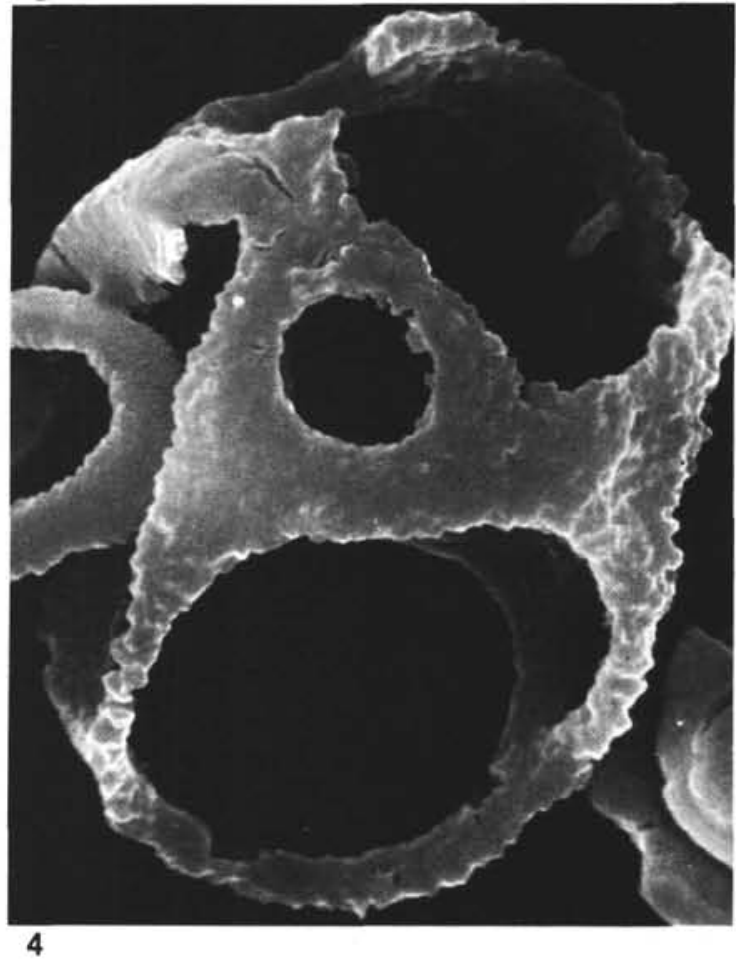

Ebridians

Magnification $2800 \times($ Figures 1, 2, 5); $5000 \times$ (Figures 3, 4).

Figures 1,2 Ebridian, gen: et sp. indet. from an otherwise not siliceous limestone sample of early Eocene age (Sample 357-28-6, $66 \mathrm{~cm}$ ).

Figures 3,4 Hermesinopsis caulleryi Deflandre (Sample 356-7-3, $70 \mathrm{~cm}$ ).

Figure 5 Ebriopsis crenulata Hovasse (Sample 356-7-3, $70 \mathrm{~cm}$ ). 